\title{
Perilaku Pemeliharaan Kebersihan Mulut Pengguna Gigi Tiruan Sebagian Lepasan Akrilik
}

\author{
Adine V. K. Herwanto, Christy N. Mintjelungan, Vonny N. S. Wowor.
}

Program Studi Pendidikan Dokter Gigi Fakultas Kedokteran Universitas Sam Ratulangi Manado, Indonesia.

Email: vaniaherwanto@gmail.com

Disubmisi: 18 Oktober 2021; direvisi: 30 Oktober 2021; diterima: 08 November 2021

\begin{abstract}
Behavior of maintaining denture hygiene is an important factor in the success of denture care. Poor denture hygiene maintenance can cause problems for dental and oral health such as caries, gingivitis, stomatitis, xerostomia, candidiasis, and periodontal disease, especially in users of acrylic-based removable dentures. This study was aimed to obtain the oral hygiene maintenance behavior of denture wearers. This was a literature review study using secondary data sources of the Google Scholar and PubMed databases with keywords, as follows: maintenance behavior, oral hygiene, denture users, acrylic removable partial dentures. Data selection were carried out based on inclusion and exclusion criteria, followed by a critical appraisal. The selection results in six literatures consisting in the form of cross-sectional studies. The results showed that the hygiene behavior of acrylic-based removable dentures in the community was classified as poor. In conclusion, maintenance of oral hygiene behavior of acrylic removable partial denture wearers is classified as poor due to lack of knowledge of most denture wearers to keep their dentures clean. Keywords: maintenance behavior of oral hygiene; denture wearers; acrylic removable partial dentures
\end{abstract}

\begin{abstract}
Abstrak: Perilaku memelihara kebersihan gigi tiruan merupakan faktor penting dalam keberhasilan perawatan gigi tiruan. Pemeliharaan kebersihan gigi tiruan yang kurang baik dapat menimbulkan masalah bagi kesehatan gigi dan mulut seperti karies, gingivitis, stomatitis, xerostomia, kandidiasis, dan penyakit periodontal, terutama pada pengguna gigi tiruan lepasan berbasis akrilik. Penelitian ini bertujuan untuk mengetahui perilaku pemeliharaan kebersihan mulut pengguna gigi tiruan sebagian lepasan (GTSL) akrilik. Jenis penelitian berbentuk literature review dengan menggunakan sumber data sekunder yang diperoleh melalui pencarian database Google Scholar dan PubMed dengan kata kunci: maintenance behavior, oral hygiene, denture users, acrylic removable partial dentures. Seleksi data dilakukan berdasarkan kriteria inklusi dan eksklusi, dilanjutkan dengan critical appraisal. Hasil seleksi mendapatkan enam literatur berbentuk cross-sectional study. Data hasil kajian menunjukkan bahwa perilaku pemeliharaaan kebersihan gigi tiruan lepasan berbasis akrilik pada masyarakat tergolong kurang baik. Simpulan penelitian ini ialah pemeliharaan kebersihan gigi mulut pengguna gigi tiruan sebagian lepasan akrilik masih tergolong kurang baik karena kurangnya kesadaran dan pengetahuan dari sebagian besar masyarakat mengenai pentingnya menjaga kebersihan gigi tiruan.
\end{abstract}

Kata kunci: perilaku pemeliharaan kebersihan mulut; pengguna gigi tiruan; gigi tiruan sebagian lepasan akrilik

\section{PENDAHULUAN}

Gigi tiruan merupakan piranti yang dibuat untuk menggantikan fungsi gigi dan jaringan lunak sekitarnya yang telah hilang.
Terdapat berbagai jenis gigi tiruan yang dapat menjadi pilihan bagi individu yang mengalami kehilangan gigi. Gigi tiruan sebagian lepasan (GTSL) merupakan salah 
satu jenis gigi tiruan yang diindikasikan pada yang kehilangan sebagian gigi aslinya. ${ }^{1}$

Gigi tiruan sebagian lepasan (GTSL) merupakan gigi tiruan yang dapat dilepas dan dipasangkan sendiri oleh penggunanya ke mulut, dengan tujuan untuk menggantikan gigi serta fungsi yang hilang serta mempertahankan struktur jaringan yang masih tertinggal. ${ }^{2}$ Memulihkan dan mempertahankan struktur jaringan merupakan tujuan utama dalam perawatan prostodontik untuk pasien yang giginya tinggal sebagian. Gigi yang hilang perlu dibuatkan penggantinya agar tidak timbul dampak yang tidak diinginkan. ${ }^{3}$

Riset Kesehatan Dasar (RISKESDAS)

Departemen Kesehatan Republik Indonesia tahun 2018 menyatakan bahwa prevalensi penggunaan gigi tiruan baik pada rahang atas maupun rahang bawah untuk menggantikan gigi yang hilang di Indonesia ialah sebesar 4,6\%. ${ }^{4}$ Di Cina prevalensi penggunaan gigi tiruan pada manula hanya sebesar 38,7\%. Di Jepang tahun 2002 prevalensi penggunaan gigi tiruan hanya mencapai $30 \%$ dari penduduk. ${ }^{5}$ Pengguna GTSL terbanyak pada kelompok usia 21-40 tahun $(54,5 \%)$ dengan tingkat pendidikan akhir SMA. Estetik merupakan alasan utama untuk memakai gigi tiruan (74\%) dibandingkan mengembalikan fungsi pengunyahan $(26 \%){ }^{6}$

Pembersihan gigi tiruan harian secara teratur harus dilakukan untuk mencegahnya plak yang menumpuk dan juga untuk membersihkan sisa-sisa makanan dari permukaan. Gigi tiruan harus dilepaskan dari mulut di malam hari untuk memungkinkan istirahat yang cukup bagi jaringan mukosa. Pemakaian gigi tiruan secara terus menerus tanpa dilepas dapat menyebabkan beberapa reaksi terhadap jaringan mukosa di bawah gigi tiruan tersebut. Oleh karena itu, gigi tiruan yang dipakai untuk jangka waktu lama dapat memblokir pembersihan mukosa mulut oleh lidah dan air liur yang akan menghasilkan penempelan mikroorganisme dan meningkatkan risiko munculnya gangguan pada kesehatan gigi dan mulut, seperti penyakit karies, penyakit periodontal dan denture stomatitis. ${ }^{7}$ Denture stomatitis atau kandidiasis atropi kronis adalah inflamasi pada membran mukosa yang sering terlihat pada palatum di bawah gigi tiruan. Dari beberapa penelitian yang telah dilakukan, jamur Candida albicans diduga mempunyai peran utama dalam patogenesis penyakit ini. ${ }^{8}$ Kebersihan mulut yang buruk merupakan salah satu dari beberapa faktor yang mempercepat pertumbuhan Candida albicans sehingga dapat menyebabkan inflamasi, eritema, dan fisura pada mukosa. ${ }^{9}$

Berdasarkan hasil penelitian yang dilakukan Rahmayani et $\mathrm{al}^{6}$ di daerah Gampong Peuniti Banda Aceh, terdapat 63\% responden yang memiliki perilaku yang kurang baik dalam menjaga kebersihan dari gigi tiruannya. Penelitian yang dilakukan oleh Muluwere et al $^{10}$ di daerah Kelurahan Batu Kota Lingkungan III Kecamatan Malalayang Manado Sulawesi Utara, menunjukkan sebanyak $80 \%$ responden memiliki pengetahuan kurang tentang pentingnya menjaga kesehatan gigi dan mulut dan pengaruhnya terhadap pemakaian gigi tiruan. Dengan mencermati hal-hal yang telah dipaparkan maka penulis terdorong untuk menelusuri lebih lanjut mengenai perilaku pemeliharaan kebersihan mulut pengguna gigi tiruan sebagian lepasan akrilik pada masyarakat di beberapa daerah di Indonesia.

\section{METODE PENELITIAN}

Jenis penelitian ini merupakan suatu literature review yang dilakukan dengan cara identifikasi, evaluasi dan interpretasi terhadap hasil penelitian tertentu. Topik yang menjadi perhatian didapat dari berbagai sumber seperti jurnal, buku, internet, dan pustaka lain dengan menggunakan database dari Google Scholar dan PubMed serta kata kunci maintenance behavior, oral hygiene, denture users, acrylic removable partial dentures.

\section{HASIL PENELITIAN}

Terdapat enam artikel yang diperoleh melalui proses reduksi data sesuai kriteria inklusi dan eksklusi serta analisis data melalui the Joanna Briggs Institute (JBI) critical appraisal. Seluruh artikel tersebut menggunakan metode studi cross-sectional. 
Tabel 1. Nama penulis, tahun publikasi, dan rangkuman hasil penelitian

\begin{tabular}{|c|c|c|}
\hline $\begin{array}{c}\text { Peneliti/ } \\
\text { Tahun }\end{array}$ & Judul & Rangkuman Hasil \\
\hline${\text { Kaliey et } \mathrm{al}^{1}}^{1}$ & $\begin{array}{l}\text { Perilaku pemeliharaan keber- } \\
\text { sihan gigi tiruan lepasan pada } \\
\text { masyarakat Desa Kema II } \\
\text { Kecamatan Kema }\end{array}$ & $\begin{array}{l}\text { Berdasarkan hasil penelitian didapat bahwa } \\
\text { perolehan skor pengetahuan masyarakat tentang } \\
\text { pemeliharaan kebersihan gigi tiruan lepasan } \\
\text { sebesar } 552 \text { yang menunjukkan bahwa pengeta- } \\
\text { huan masyarakat tergolong kurang baik. }\end{array}$ \\
\hline $\begin{array}{l}\text { Rahmayani et } \\
\mathrm{al}^{6}\end{array}$ & $\begin{array}{l}\text { Oral hygiene behavior of } \\
\text { acrylic removable partial den- } \\
\text { ture usage in Seuneubok } \\
\text { District, West Aceh: a cross- } \\
\text { sectional study }\end{array}$ & $\begin{array}{l}\text { Perilaku pemeliharaan dan kebersihan mulut } \\
\text { masyarakat dengan gigi tiruan sebagian lepasan } \\
\text { akrilik di Aceh Bara Seuneubok sebagian besar } \\
\text { dalam kategori kurang baik }\end{array}$ \\
\hline $\begin{array}{l}\text { Adhiathmitha } \\
\text { et } \mathrm{al}^{8}\end{array}$ & $\begin{array}{l}\text { Faktor-faktor yang berkaitan } \\
\text { dengan tingkat perilaku peme- } \\
\text { liharaan kebersihan gigi tiruan } \\
\text { lepasan akrilik pada lansia di } \\
\text { Desa Penatahan Kabupaten } \\
\text { Tabanan Bali }\end{array}$ & $\begin{array}{l}\text { Tingkat perilaku pemeliharaan kebersihan gigi } \\
\text { tiruan lepasan akrilik pada lansia di Desa } \\
\text { Penatahan, Kabupaten Tabanan, Bali ialah } 6 \\
\text { orang responden }(10,3 \%) \text { memiliki tingkat } \\
\text { perilaku yang baik, } 24 \text { orang responden }(41,4 \%) \\
\text { memiliki tingkat perilaku yang kurang baik, dan } \\
\text { sebanyak } 28 \text { orang }(48,3 \%) \text { memiliki tingkat } \\
\text { perilaku yang tidak baik }\end{array}$ \\
\hline Bagaray et al ${ }^{11}$ & $\begin{array}{l}\text { Perilaku memelihara kebersih- } \\
\text { an gigi tiruan lepasan berbasis } \\
\text { akrilik pada masyarakat Desa } \\
\text { Treman Kecamatan Kauditan }\end{array}$ & $\begin{array}{l}\text { Perilaku memeliharan kebersihan gigi tiruan } \\
\text { lepasan berbasis akrilik pada masyarakat Desa } \\
\text { Treman Kecamatan Kauditan tergolong dalam } \\
\text { kategori cukup. }\end{array}$ \\
\hline Titjo et al ${ }^{12}$ & $\begin{array}{l}\text { Perilaku masyarakat pengguna } \\
\text { gigi tiruan sebagian lepasan di } \\
\text { Kelurahan Bahu }\end{array}$ & $\begin{array}{l}\text { Berdasarkan hasil penelitian yang telah dilakukan } \\
\text { dalam penelitian ini, didapat bahwa pengetahuan } \\
\text { masyarakat pengguna gigi tiruan lepasan di } \\
\text { Kelurahan Bahu termasuk pada kategori cukup } \\
\text { dengan skor } 433 \text {. }\end{array}$ \\
\hline $\begin{array}{l}\text { Mapanawang } \\
\text { et al }{ }^{13}\end{array}$ & $\begin{array}{l}\text { Gambaran pemeliharaan keber- } \\
\text { sihan GTL akrilik pada masya- } \\
\text { rakat kelurahan Batu Putih } \\
\text { Bawah }\end{array}$ & $\begin{array}{l}\text { Hasil penelitian yang diperoleh menunjukkan } \\
\text { bahwa mayoritas masyarakat pengguna GTL } \\
\text { Akrilik tidak pernah mendapatkan instruksi } \\
\text { secara lisan maupun tulisan pasca pemasangan } \\
\text { GTL Akrilik. }\end{array}$ \\
\hline
\end{tabular}

\section{BAHASAN}

Banyak responden yang tidak mengetahui cara pemeliharaan kebersihan gigi tiruan yang baik dan benar. Adhiatmitha et $\mathrm{al}^{8}$ menyatakan bahwa hanya sebagian kecil responden yang selalu membersihkan gigi tiruan lepasannya setelah makan. Sebagian besar responden menggunakan gigi tiruan saat tidur, dan hanya membersihkan gigi tiruannya dengan menggunakan air tanpa menggunakan pasta gigi ataupun bahan pembersih gigi tiruan. Hal tersebut didukung oleh penelitian oleh Bagaray et $\mathrm{al}^{11}$ yang melaporkan bahwa mayoritas pengguna GTSL hanya sekedar menggunakan tanpa mengetahui dampak, fungsi, dan manfaat dari pemakaian gigi tiruan. Selain itu, terdapat hubungan bermakna antara kesadaran diri, tingkat pengetahuan, kete- patan edukasi dalam perilaku kebersihan mulut dan penggunaan gigi tiruan. ${ }^{11}$

Rahmayani ${ }^{6}$ juga mengemukakan bahwa banyak responden mengatakan tidak pernah melakukan konsultasi kepada dokter gigi selama penggunaan gigi tiruan. Hal itu disebabkan oleh pendapat responden yaitu tidak ada masalah pada rongga mulut mereka selama penggunaan gigi tiruan sehingga tidak perlu melakukan kunjungan atau pemeriksaan ke dokter gigi.

Selain masalah pemeliharaan kebersihan, Kaliey et $\mathrm{al}^{1}$ juga menemukan masalah pada pembuatan gigi tiruan yang tidak dilakukan oleh dokter gigi melainkan oleh tukang gigi yang tidak diikuti oleh pemberian informasi tentang pentingnya perawatan kebersihan gigi tiruan karena dapat berdampak pada kesehatan rongga mulut. 
Penelitian yang dilakukan Rahmayani et $\mathrm{al}^{6}$ menyatakan bahwa terdapat hubungan bermakna antara perilaku kebersihan mulut dan durasi penggunaan gigi tiruan. Kebersihan gigi yang baik atau buruk tidak bergantung pada durasi pemakaian gigi tiruan, tetapi tergantung pada pengetahuan dan kesadaran individu dalam menjaga kebersihan mulut selama penggunaan GTSL. Perlu diperhatikan bahwa prosedur dan motivasi kebersihan pribadi pasien bersama dengan program kebersihan mulut yang diawasi dapat berperan penting untuk mencegah segala kemungkinan efek kerusakan pada kesehatan jaringan mulut.

Perawatan gigi tiruan memiliki perbedaan menurut tingkat pendidikan dan penghasilan seseorang karena setiap orang mempunyai tujuan, motivasi, dan pengetahuan yang berbeda pula. Titjo et $\mathrm{al}^{12}$ menyatakan bahwa semakin tinggi penghasilan dan tingkat pendidikan seseorang, maka tingkat pengetahuannya pun akan semakin bertambah karena adanya kemampuan untuk menyerap informasi semakin tinggi. Demikian pula dengan kemudahan untuk mengakses berbagai sumber informasi termasuk tentang kesehatan gigi. Hal ini didukung juga oleh Mapanawang et $\mathrm{al}^{13}$ yang menyatakan bahwa tingkat pendidikan seseorang sangat berpengaruh pada perawatan gigi tiruan dikarenakan tingkat pendidikan berpengaruh langsung pada kesadaran. Pengetahuan seseorang sangat berdampak dalam keputusan untuk menggunakan gigi tiruan atau tidak, termasuk juga pada perilaku dalam memelihara kebersihan gigi tiruan yang digunakannya.

\section{SIMPULAN}

Perilaku pemeliharaan kebersihan gigi gigi mulut pengguna gigi tiruan sebagian lepasan akrilik tergolong kurang baik karena kurangnya kesadaran dan pengetahuan dari sebagian besar masyarakat mengenai pentingnya menjaga kebersihan gigi tiruan.

\section{Konflik Kepentingan}

Penulis menyatakan tidak terdapat konflik kepentingan dalam studi ini.

\section{DAFTAR PUSTAKA}

1. Kaliey IP, Wowor VNS, Lampus BS. Perilaku pemeliharaan kebersihan gigi tiruan lepasan pada masyarakat Desa Kema II Kecamatan Kema. e-GiGi. 2016;4(2).

2. Susanto H, Hestiningsih R, Udijono A, Hubungan perilaku pemeliharaan dengan kondisi gigi tiruan lepasan pada masyarakat di wilayah kerja Puskesmas Bandarharjo Kota Semarang. Jurnal Kesehatan Masyarakat. 2017;5(4):500-4.

3. Baba P, Wowor VNS, Tendean L. Hubungan perilaku pemeliharaan kebersihan dengan status gingiva pada pengguna gigi tiruan sebagian lepasan. e-GiGi. 2018;6(1):6-12.

4. Mangundap GCM, Wowor VNS, Mintjelungan $\mathrm{CN}$. Efektivitas penggunaan gigi tiruan sebagian lepasan terhadap fungsi pengunyahan pada masyarakat Desa Pinasungkulan Kecamatan Modoinding. eGiGi. 2019;7(2):81-6.

5. Khoman JA, Mariati NW, Siagian ED. Profil pemakaian gigi tiruan lepasan berbasis akrilik pada masyarakat Kelurahan Bahu Kecamatan Malalayang. Jurnal Biomedik. 2013;4(1):43-51.

6. Rahmayani L, Sofya P, Andriany P, Jingga C. Oral hygiene behavior of acrylic removable partial denture usage in Seuneubok District, West Aceh: a crosssectional study. Journal International Oral Health. 2020;12(2):163-7.

7. Subrata G, Rahajoeningsih P, Wartadewi. Efektivitas beberapa macam bahan pembersih gigi tiruan terhadap pertumbuhan Candida albicans dari gigi tiruan lengkap akrilik rahang atas secara in vitro [Laporan penelitian]. Bandung: Universitas Padjadjaran; 1998.

8. Adhiatmitha KE, Ni Kd FR Pertiwi, Susanti DNA. Faktor-faktor yang berkaitan dengan tingkat perilaku pemeliharaan kebersihan gigi tiruan lepasan akrilik pada lansia di Desa Penatahan Kabupaten Tabanan Bali. Bali Dental Journal. 2018;2(1):17-23.

9. Sherlyta M, Wardani R, Susilawati S. Tingkat kebersihan gigi dan mulut siswa Sekolah Dasar Negeri di desa tertinggal Kabupaten Bandung (Oral hygiene level of underdeveloped village state Elementary School students in Bandung Regency). Jurnal Kedokteran Gigi Universitas Padjadjaran. 2017;29(1):69-76. 
10. Muluwere V, Mariati NW, Wicaksono AD, Gambaran pengetahuan dan status kebersihan pada pemakai gigi tiruan sebagian lepasan di Kelurahan Batu Kota Kecamatan Malalayang. e-GiGi. 2015:3(1)

11. Bagaray DA, Mariati NW, Leman MA. Perilaku memelihara kebersihan gigi tiruan lepasan berbasis akrilik pada masyarakat Desa Treman Kecamatan
Kauditan. e-GiGi. 2014;2(2).

12. Titjo OC, Lampus BS, Juliatri. Perilaku masyarakat pengguna gigitiruan lepasan di Kelurahan Bahu. e-GiGi. 2013;1(2).

13. Mapanawang BN, Kaunang WPJ, Wowor VNS. Gambaran pemeliharaan kebersihan GTL akrilik pada masyarakat Kelurahan Batu Putih Bawah. e-GiGi. 2014;2(1). 